\title{
Alterations in Phenotypes and Responses of T Cells Within 6 Months of Recovery from COVID-19: A Cohort Study
}

\author{
Bali Zhao ${ }^{1,9} \cdot$ Maohua Zhong ${ }^{2} \cdot$ Qingyu Yang ${ }^{1,5,6} \cdot \mathrm{Ke} \mathrm{Hong}^{5,6} \cdot$ Jianbo Xia ${ }^{7} \cdot \mathrm{Xia} \mathrm{Li}^{5,6} \cdot \mathrm{Ying}^{5 i u^{6,8}}$ • \\ Yao-Qing Chen ${ }^{3}$ (D) Jingyi Yang ${ }^{4}$ (1) Chaolin Huang ${ }^{5,6}$ (D) Huimin Yan ${ }^{1,4,9}$ (D)
}

Received: 11 October 2020 / Accepted: 30 November 2020 / Published online: 9 February 2021

(C) Wuhan Institute of Virology, CAS 2021

\begin{abstract}
The COVID-19 pandemic, caused by the SARS-CoV-2 infection, is a global health crisis. While many patients have clinically recovered, little is known about long-term alterations in T cell responses of COVID-19 convalescents. In this study, $\mathrm{T}$ cell responses in peripheral blood mononuclear cells of a long-time COVID-19 clinically recovered (20-26 weeks) cohort (LCR) were measured via flow cytometry and ELISpot. The T cell responses of LCR were comparatively analyzed against an age and sex matched short-time clinically recovered (4-9 weeks) cohort (SCR) and a healthy donor cohort (HD). All volunteers were recruited from Wuhan Jinyintan Hospital, China. Phenotypic analysis showed that activation marker PD-1 expressing on $\mathrm{CD}^{+}{ }^{+} \mathrm{T}$ cells of LCR was still significantly lower than that of HD. Functional analysis indicated that frequencies of Tc2, Th2 and Th17 in LCR were comparable to those of HD, but Tc17 was higher than that of HD. In LCR, compared to the HD, there were fewer IFN- $\gamma$ producing $\mathrm{T}$ cells but more IL-2 secreting T cells. In addition, the circulating Tfh cells in LCR were still slightly lower compared to HD, though the subsets composition had recovered. Remarkably, SARS-CoV-2 specific T cell responses in LCR were comparable to that of SCR. Collectively, $\mathrm{T}$ cell responses experienced long-term alterations in phenotype and functional potential of LCR cohort. However, after clinical recovery, SARS-CoV-2 specific T cell responses could be sustained at least for six months, which may be helpful in resisting re-infection.
\end{abstract}

Keywords COVID-19 $\cdot$ Long-time recovery $\cdot$ Peripheral T cells

Electronic supplementary material The online version of this article (https://doi.org/10.1007/s12250-021-00348-0) contains supplementary material, which is available to authorized users.

$\square$ Huimin Yan
hmyan@ wh.iov.cn
Chaolin Huang
chaolin2020@163.com
$\square$ Jingyi Yang
jyyang875@163.com
Yao-Qing Chen
chenyaoqing@mail.sysu.edu.cn
1 State Key Laboratory of Virology, Wuhan Institute of
Virology, Center for Biosafety Mega-Science, CAS,
Wuhan 430071, China
Institute of Infection, Immunology and Tumor
Microenvironment, Hubei Province Key Laboratory of
Occupational Hazard Identification and Control, Medical
College, Wuhan University of Science and Technology,
Wuhan 430065, China

3 School of Public Health (Shenzhen), Sun Yat-Sen University, Shenzhen 518107, China

4 Shanghai Public Health Clinical Center, Fudan University, Shanghai 201508, China

5 Joint Laboratory of Infectious Diseases and Health, Wuhan Institute of Virology \& Wuhan Jinyintan Hospital, Wuhan Jinyintan Hospital, Wuhan 430023, China

6 Center for Translational Medicine, Jinyintan Hospital, Wuhan 430023, China

7 Department of Laboratory Medicine, Maternal and Child Health Hospital of Hubei Province, Tongji Medical College, Huazhong University of Science and Technology, Wuhan 430070, China

8 The Office of Drug Clinical Trial Institution, Jinyintan Hospital, Wuhan 430023, China

9 University of Chinese Academy of Sciences, Beijing 100049, China 


\section{Introduction}

The worldwide pandemic COVID-19 caused by SARS$\mathrm{CoV}-2$, remains a global threat to both humans and society. As of November 30, 2020, there were over 61 million confirmed infections globally, with more than 1.4 million deaths. Seeing as tens of thousands of patients have clinically recovered, whether this population could resist reinfection for a long period of time is a question attracting more and more attention.

Long-lasting B cell memory and the highest affinity pathogen-specific antibodies are critical for resistance against re-infection. However, antibody responses to SARS-CoV-2 appear to have declined in a large percentage of individuals (Long et al. 2020). The striking absence of germinal centers, the defective generation of $\mathrm{Bcll}^{+} \mathrm{T}$ follicle helper (Tfh) cells, and dysregulated humoral immune induction early in COVID-19 disease, provide a mechanistic explanation for the limited durability of antibody responses (Kaneko et al. 2020).

The $\mathrm{T}$ cell is another important cell type for eliminating infection and establishing long-term immunity from the coronavirus infection (Liu et al. 2017; Callaway 2020; Corey et al. 2020; Leslie 2020). For SARS-CoV-2 infection, T cells were activated (Mathew et al. 2020; Thevarajan et al. 2020), and the specific T cell response could be established (Cox and Brokstad 2020; Grifoni et al. 2020; Peng et al. 2020; Sekine et al. 2020). However, a decreased number of $\mathrm{T}$ cells with impaired function is prominent in COVID-19 patients, especially in severe cases (Qin et al. 2020; Zhang et al. 2020; Zhou et al. 2020; Zhu et al. 2020). Moreover, broad phenotypic alterations and potential dysfunctions were still prominent in those $\mathrm{T}$ cells in individuals clinically recovered from COVID-19 (Yang et al. 2020a, b). It is still unknown, after being recovered for a long time, whether the altered non-specific $\mathrm{T}$ cell responses could bounce back and whether the specific $\mathrm{T}$ cell responses are sustainable.

In August, 2020, individuals who had clinically recovered from COVID-19 were initially enrolled in this study at Wuhan Jinyintan Hospital. A COVID-19 long-time clinically recovered (20-26 weeks) cohort (LCR) was recruited amongst these individuals. To analyze changes in $\mathrm{T}$ cell responses of LCR, a healthy donor cohort (HD) who matched the age and sex of the LCR, and a short-time clinically recovered (4-9 weeks) cohort (SCR) were also established. Phenotype and functional potential of the $\mathrm{T}$ cells in the freshly isolated peripheral blood mononuclear cells (PBMCs) were analyzed by FACS and ELISpot assay.

\section{Materials and Methods}

\section{Clinical Laboratory Measurements}

Clinical laboratory measurements including complete blood count, SARS-CoV-2 receptor binding domain (RBD) specific antibody detection, and SARS-CoV-2 specific nucleotide detection were performed at Wuhan Jinyintan Hospital. Nasopharyngeal swab samples were collected on the day of peripheral blood collection and were measured via qRT-PCR for amplification of $E$ gene, $R d R p$ gene, and $N$ gene of SARS-CoV-2 as previously described (Cao et al. 2020).

\section{Study Design and Participants}

In August, 2020, a total of 64 individuals who had clinically recovered from documented COVID-19 were recruited at Wuhan Jinyintan Hospital. Fifty-eight of them were enlisted following recovery from COVID-19 within 20-26 weeks, and were confirmed negative for SARSCoV-2 on the day of sampling. Then, one individual with severe chronic disease was excluded. The remaining 57 subjects (26 males and 31 females) with a mean age of 51 years old composed the long-time clinically recovered cohort (LCR) (Fig. 1). Among the individuals in LCR cohort, six subjects experienced severe COVID-19.

Among the 74 enrolled COVID-19 clinically recovered volunteers in April, 2020, 65 of them (recovery within 4-9 weeks) were initially recruited. Three individuals with detectable virus RNA, and one individual with severe chronic disease was not admitted to the study. To match the age and sex of the LCR cohort, three young females were omitted (Supplementary Fig. S1). The remaining 58 subjects (26 males and 32 females) with a mean age of 50 years old, were designated as a short-time clinically recovered cohort (SCR). There were three participants who had a history of severe COVID-19 in SCR cohort.

In addition, 61 healthy individuals without documented SARS-CoV-2 infection were initially recruited when having their regular physical examination at Wuhan Jinyintan Hospital in April of 2020. Two subjects were excluded due to the positive IgM and IgG antibodies response against the SARS-CoV-2 in serum. In order to match the other two cohorts in age and sex, three young females and four young males were excluded (Supplementary Fig. S1). Finally, a total of 52 subjects were included in the healthy donor cohort (HD) containing 23 males and 29 females. The mean age of this cohort was 50 years old. 
Fig. 1 The process of participants selection. Participants in the three cohorts were selected based on the parameters listed to the left of the figure.

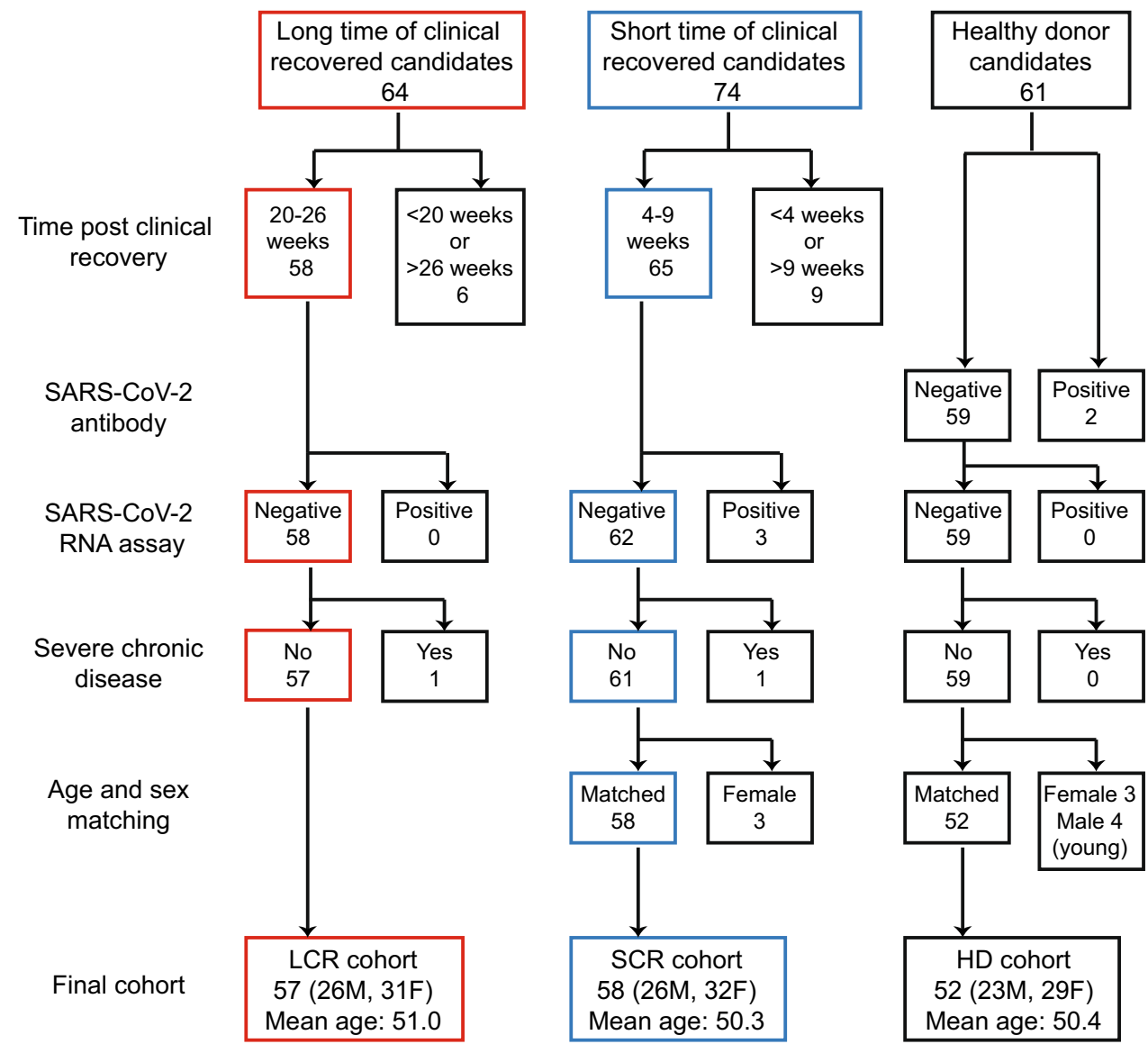

For ELISpot assay, due to the cost and labor-intensity, a sub-cohort of only 27 individuals in SCR and a sub-cohort of 18 individuals in HD were involved in the test.

\section{Flow Cytometry}

Cell pellets from the fresh peripheral blood of participates were separated by centrifugation. After density centrifugation, the white cell layers were aspirated and washed by cold PBS twice. The obtained PBMCs were resuspended in RPMI 1640 medium for further use.

In order to evaluate the activation, proliferation, and differentiation of $\mathrm{T}$ cells, single-cell suspensions of PBMCs were surface stained with monoclonal antibodies (mAbs) specific to CD3 (HIT3a), CD4 (OKT4), CD8 (RPA-T8), CD45RO (UCHL1), CD27 (O323), HLA-DR (L243), CD38 (HB-7), PD-1 (EH12.2H7) and Fixable Viability Dye eFluor ${ }^{\mathrm{TM}} 506$ (eBioscience, San Diego, CA, USA) at $4{ }^{\circ} \mathrm{C}$ for $30 \mathrm{~min}$. After washing, cells were fixed and permeabilized with Foxp3/Transcription Factor Staining Buffer Set (eBioscience, San Diego, CA, USA) for $12 \mathrm{~h}$, and were then incubated with mAbs specific to T-bet (4B10), ROR $\gamma \mathrm{t}$ (AFKJS-9) and Ki-67 (Ki-67) at $4{ }^{\circ} \mathrm{C}$ for $30 \mathrm{~min}$.
To detect the proliferation and activation of Tfh cells, PBMCs were surfaced stained with mAbs specific to CD3 (HIT3a), CD4 (RPA-T4), CD8 (RPA-T8), CXCR5 (J252D4), CXCR3 (G025H7), CCR6 (G034E3), PD-1 (EH12.2H7), ICOS (C398.4A), and Fixable Viability Dye eFluor ${ }^{\mathrm{TM}} 506$ at $4{ }^{\circ} \mathrm{C}$ for $30 \mathrm{~min}$. Cells were then fixed and permeabilized (eBioscience, San Diego, CA, USA) overnight prior to incubation with mAb specific to Ki-67 (Ki67).

For detection of cytokine production with non-specific stimulation, obtained PBMCs were stimulated for $4.5 \mathrm{~h}$ at $37{ }^{\circ} \mathrm{C}$ with $200 \mathrm{ng} / \mathrm{mL}$ PMA (Beyotime, Shanghai, China) and $2000 \mathrm{ng} / \mathrm{mL}$ ionomycin (Beyotime, Shanghai, China) in the presence of $1 \mu \mathrm{mol} / \mathrm{L}$ monensin (BioLegend, San Diego, CA, USA) and $2.5 \mu \mathrm{g} / \mathrm{mL}$ Brefeldin A (BioLegend, San Diego, CA, USA). Cells were then labeled with Fixable Viability Dye eFluor ${ }^{\mathrm{TM}} 506$ and $\mathrm{mAbs}$ specific to CD3 (HIT3a), CD4 (OKT4) and CD8 (RPA-T8) at $4{ }^{\circ} \mathrm{C}$ for $30 \mathrm{~min}$. After being fixed using Fixation buffer for $30 \mathrm{~min}$ at $4{ }^{\circ} \mathrm{C}$, those cells were permeabilized overnight and were then intracellularly stained with mAbs specific to IL-2 (MQ1-17H12), IL-21(3A3-N2), IFN- $\gamma$ (4S.B3), IL-4 (MP4-25D2), IL-17A (BL168) and granzyme B (QA16A02) at $4{ }^{\circ} \mathrm{C}$ for $30 \mathrm{~min}$. 
All antibodies were bought from BioLegend (San Diego, CA, USA) or eBioscience (San Diego, CA, USA). Stained cells were run on an LSRFortessa (BD, Heidelberg, Germany) and analyzed with FlowJo V 7.0 software.

\section{Enzyme-Linked Immunospot Assay (ELISpot)}

IFN- $\gamma$ producing $\mathrm{T}$ cells were assessed by ELISpot under the manufacturer's instructions. Briefly, PVDF-membranebottomed plates (Millipore, Bedford, MA, USA) were coated overnight with an anti-human IFN- $\gamma$ coating antibody at $4{ }^{\circ} \mathrm{C}$. After blocking, single cell suspensions of PBMCs were seeded onto the plates $\left(1 \times 10^{5}\right.$ cells/well $)$, and were stimulated with N, S1, and S2 proteins of SARS$\mathrm{CoV}-2$, and p24 protein of HIV-1 for $45 \mathrm{~h}$ at $37{ }^{\circ} \mathrm{C}, 5 \%$ $\mathrm{CO}_{2}$, respectively. The final concentration of each protein was $2 \mu \mathrm{g} / \mathrm{mL}$. Then cells were removed, and biotinconjugated $\mathrm{mAb}$ was applied prior to adding streptavidinHRP. After washing, spots were developed with AEC coloring system, and the number of spots were counted by an automatic ELISpot reader (AID, Strassberg, Germany).

IFN- $\gamma$ ELISpot antibody pair was purchased from U-CyTech biosciences (Utrecht, Netherlands), the SARSCoV-2 N protein was kindly provided by Professor Ningshao Xia at Xiamen University, while the SARS-CoV-2 S1 and S2 proteins were bought from Sino Biological Company (Beijing, China).

\section{Statistical Analysis}

Results were expressed as mean \pm S.D. unless otherwise indicated. Statistical analyses were performed using GraphPad Prism version 8.3 software (GraphPad Software Inc., San Diego, CA, USA), and data were considered to be statistically significant if $P<0.05$. One-way analysis of variance (ANOVA) with Tukey's multiple comparison was carried out to compare differences between the three cohorts. Two-way ANOVA was used to analyze ELISpot results. The chi-square test was used to analyze the difference in sex distribution of the three cohorts.

\section{Results}

\section{Phenotypic Alteration in T Cells of LCR}

In the LCR cohort, despite the fact that the percentage of $\mathrm{CD}^{+}{ }^{+} \mathrm{T}$ cells was significantly higher than that in SCR (Fig. 2A), percentages of $\mathrm{CD}^{+} \mathrm{T}$ and $\mathrm{CD} 4^{+} \mathrm{T}$ cells were comparable to those of the HD cohort (Fig. 2A). After learning this, we focused on the phenotypic changes in the $\mathrm{T}$ cells of $\mathrm{LCR}$.
In terms of activation, frequencies of $\mathrm{HLA}-\mathrm{DR}^{+}$in $\mathrm{CD}^{+}{ }^{+} \mathrm{T}$ or $\mathrm{CD}^{+} \mathrm{T}$ cells of the $\mathrm{LCR}$ cohort were both comparable with those of SCR and HD, respectively (Fig. 2B). However, similar to that of SCR, the frequency of PD- $1^{+}$in $\mathrm{CD} 4^{+} \mathrm{T}$ cells of LCR was still significantly lower than that of the HD cohort (Fig. 2C). Moreover, in terms of proliferation, also similar to that of SCR, frequency of $\mathrm{Ki}-67^{+}$in $\mathrm{CD} 8^{+} \mathrm{T}$ cells of LCR was still significantly higher than that of the HD cohort (Fig. 2D). Whereas, in terms of differentiation, frequencies of effector $\mathrm{T}$ cells $\left(\mathrm{CD} 45 \mathrm{RO}^{-} \mathrm{CD} 27^{-}\right.$, Teff) and effector memory $\mathrm{T}$ cells $\left(\mathrm{CD} 45 \mathrm{RO}^{+} \mathrm{CD} 27^{-}, \mathrm{Tem}\right)$ in $\mathrm{CD}^{+}{ }^{+} \mathrm{T}$ cells of $\mathrm{LCR}$ both became lower than those of SCR (Fig. 2E). Furthermore, the frequencies of naïve $\mathrm{T}$ cells (Tna) in $\mathrm{CD} 8^{+} \mathrm{T}$ cells and central memory $\mathrm{T}$ cells $\left(\mathrm{CD} 45 \mathrm{RO}^{+} \mathrm{CD} 27^{+}, \mathrm{Tcm}\right)$ in the $\mathrm{CD}^{+}{ }^{+} \mathrm{T}$ cells of LCR both became higher than those of SCR. For LCR, the frequencies of Teff, Tem, Tcm and Tna in either $\mathrm{CD}^{+} \mathrm{T}$ cells or $\mathrm{CD} 4^{+} \mathrm{T}$ cells all became comparable to those of HD (Fig. 2E).

\section{Functional Potential Alteration in T Cells of LCR}

Next, we evaluated the functional potential of non-specific $\mathrm{T}$ cells. In $\mathrm{CD} 8^{+} \mathrm{T}$ and $\mathrm{CD} 4^{+} \mathrm{T}$ cells, transcription factor T-bet expressing cells were often deemed as Tc1 and Th1 cells respectively (Lucas et al. 2020). Without stimulation, the frequencies of transcription factor T-bet ${ }^{+}$in $\mathrm{CD}^{+} \mathrm{T}$ or $\mathrm{CD} 4^{+} \mathrm{T}$ cells of the LCR cohort showed no difference to that of the SCR or HD cohort (Fig. 3A, 3B). Surprisingly, under polyclonal stimulation, frequencies of IFN- $\gamma^{+}$in either $\mathrm{CD}^{+} \mathrm{T}$ or $\mathrm{CD} 4^{+} \mathrm{T}$ cells of the LCR cohort were remarkably lower than that of HD (Fig. 3C, 3D), but almost the same as that of SCR.

Intriguingly, frequencies of $\mathrm{IL}-2^{+}$in either $\mathrm{CD} 8^{+} \mathrm{T}$ or $\mathrm{CD} 4^{+} \mathrm{T}$ cells of LCR became significantly higher than that of SCR and HD (Fig. 3E, 3F). Further analysis showed that compared to the HD cohort, frequencies of IFN- $\gamma^{+} \mathrm{IL}^{-2}{ }^{-}$in $\mathrm{CD}^{+} \mathrm{T}$ or $\mathrm{CD}^{+}{ }^{+} \mathrm{T}$ cells of the $\mathrm{LCR}$ cohort were reduced, while frequencies of IFN- $\gamma^{-} \mathrm{IL}^{+}{ }^{+}$in $\mathrm{CD} 8^{+} \mathrm{T}$ or $\mathrm{CD} 4^{+} \mathrm{T}$ cells were elevated (Supplementary Fig. S2A). In addition, compared to $\mathrm{HD}$, the frequencies of IFN $-\gamma^{+} \mathrm{GZMB}^{-}$in $\mathrm{CD} 8^{+} \mathrm{T}$ or $\mathrm{CD} 4^{+} \mathrm{T}$ cells of the LCR cohort were reduced, however, frequencies of IFN $-\gamma^{-} \mathrm{GZMB}^{+}$in $\mathrm{CD}^{+} \mathrm{T}$ cells of LCR were surprisingly elevated (Supplementary Fig. S2B), though the frequencies of $\mathrm{GZMB}^{+}$in $\mathrm{CD}^{+} \mathrm{T}$ or $\mathrm{CD}^{+} \mathrm{T}$ cells showed no difference between the three cohorts (Fig. 3G, 3H).

For LCR, frequencies of IL- $4^{+}$in $\mathrm{CD} 8^{+} \mathrm{T}$ and $\mathrm{CD} 4^{+} \mathrm{T}$ cells were comparable to that of SCR and HD (Fig. 3I, 3J). It should be noted that the frequency of IL- $17 \mathrm{~A}^{+}$in $\mathrm{CD} 8^{+}$ $\mathrm{T}$ cells of LCR were much higher than that of SCR, and even higher than that of HD (Fig. 3K). The frequency of IL-17A ${ }^{+}$in $\mathrm{CD}^{+}{ }^{+} \mathrm{T}$ cells of $\mathrm{LCR}$ was also much greater 
A

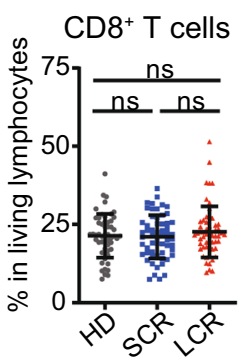

C
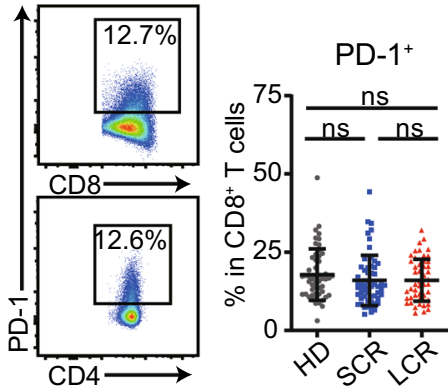

E
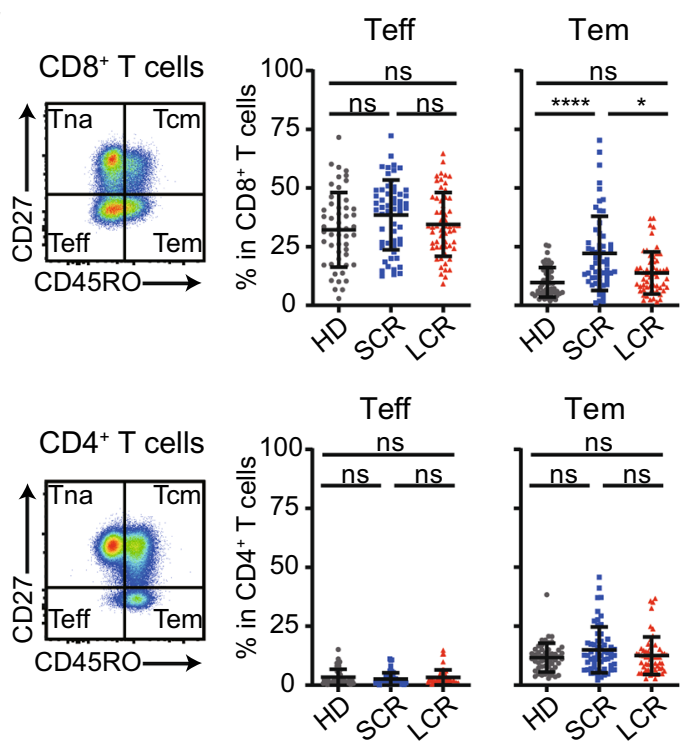

Fig. 2 The percentages, activation, proliferation and differentiation of $\mathrm{CD}^{+} \mathrm{T}$ and $\mathrm{CD} 4^{+} \mathrm{T}$ cells in PBMCs of HD, SCR and LCR cohorts. PBMCs were stained and analyzed by flow cytometry. A Frequencies of living $\mathrm{CD} 8^{+} \mathrm{T}$ cells and living $\mathrm{CD} 4^{+} \mathrm{T}$ cells in lymphocytes. $\mathbf{B}$, C Representative plots and cumulative frequencies of activation markers HLA-DR $(\mathbf{B})$ and PD-1 (c) expressing on $\mathrm{CD} 8^{+} \mathrm{T}$ and $\mathrm{CD} 4^{+}$ $\mathrm{T}$ cells. D Representative plots and cumulative frequencies of

than that of SCR, but comparable with HD (Fig. 3L). Moreover, in $\mathrm{CD}^{+}{ }^{+} \mathrm{T}$ cells of $\mathrm{LCR}$, the frequency of IL$21^{+}$cells, which are mainly composed of $\mathrm{T}$ follicular helper (Tfh) cells and Th17 cells (Long et al. 2019), was much higher than that of SCR, but similar to HD (Supplementary Fig. S3).
B

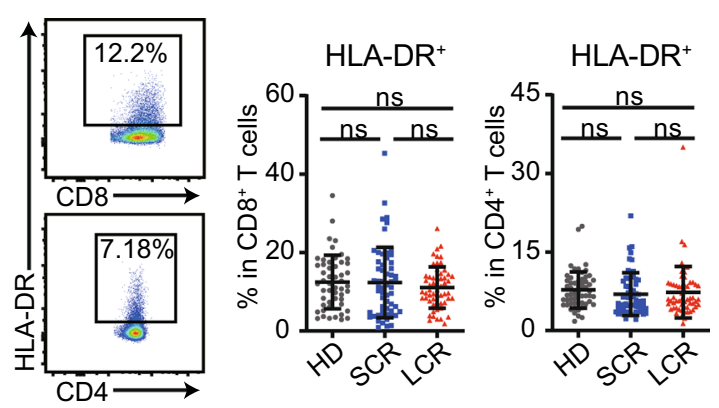

D

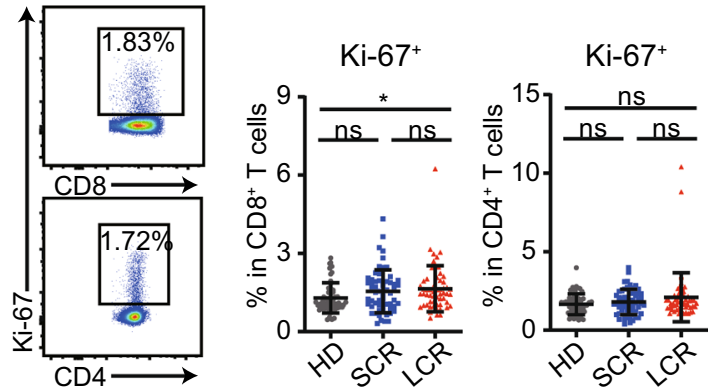

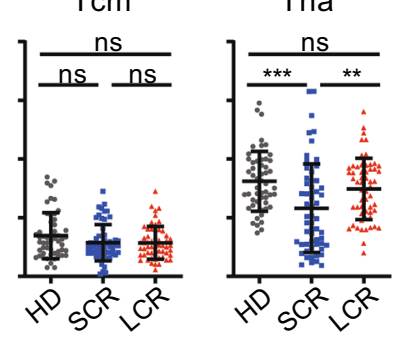

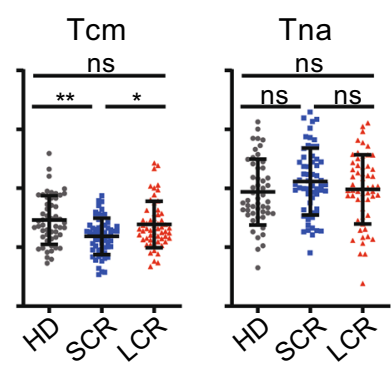

proliferated Ki- $67^{+} \mathrm{CD} 8^{+} \mathrm{T}$ and $\mathrm{CD} 4^{+} \mathrm{T}$ cells. $\mathbf{E}$ Gating strategies and frequencies of Teff $\left(\mathrm{CD}_{4} 5 \mathrm{RO}^{-} \mathrm{CD} 27^{-}\right)$, Tem $\left(\mathrm{CD} 45 \mathrm{RO}^{+}\right.$ $\left.\mathrm{CD} 27^{-}\right)$, Tcm $\left(\mathrm{CD} 45 \mathrm{RO}^{+} \mathrm{CD} 27^{+}\right)$, and $\mathrm{Tna}\left(\mathrm{CD} 45 \mathrm{RO}^{-} \mathrm{CD} 27^{+}\right)$ cells in $\mathrm{CD}^{+} \mathrm{T}$ and $\mathrm{CD}^{+} \mathrm{T}$ cells. Results are expressed as mean \pm S.D. Data were analyzed with one-way ANOVA. ns, nonsignificant; $* P<0.05 ; * * P<0.01 ; * * * P<0.001 ; * * * * P<0.0001$.

\section{Eventually Resumed Circulating Tfh Cells}

Tfh cells, with CXCR5 as a marker, are the specialized subset of $\mathrm{CD}^{+}{ }^{+} \mathrm{T}$ cells needed for germinal centers and related B cell responses (Crotty 2019). Both the frequencies of $\mathrm{CXCR}^{+}$cells and circulating $\mathrm{Tfh}$ (cTfh, PD $-{ }^{+} \mathrm{CXCR}^{+}$) cells in $\mathrm{CD} 4^{+} \mathrm{T}$ cells of the LCR cohort 
Fig. 3 Potential capability of $\mathrm{CD}^{+} \mathrm{T}$ and $\mathrm{CD} 4^{+} \mathrm{T}$ cells in PBMCs of HD, SCR and LCR cohorts to secrete cytokines. A, B PBMCs were co-stained with phenotypic markers and nuclear transcription factor T-bet, representative plots and cumulative frequencies of T-bet $^{+} \mathrm{CD}^{+} \mathrm{T}(\mathbf{A})$ and $\mathrm{CD} 4^{+}$

$\mathrm{T}$ (B) cells were shown. $\mathbf{C}-\mathbf{I}$ PBMCs were stimulated with PMA and ionomycin for $4.5 \mathrm{~h}$ in the presence of BFA and monensin. Production of IFN- $\gamma$ (C, D), IL-2 (E, F), granzyme B (G, H), IL-4 (I, J) and IL-17A $(\mathbf{K}, \mathbf{L})$ by $\mathrm{CD}^{+}{ }^{+} \mathrm{T}$ or by $\mathrm{CD} 4^{+}$ $\mathrm{T}$ cells were intracellularly stained and analyzed by flow cytometry. Results are shown as mean \pm S.D. Data were analyzed with one-way ANOVA. ns, non-significant; $* P<0.05 ; * * P<0.01$;

$* * * P<0.001$ $* * * * P<0.0001$.
A
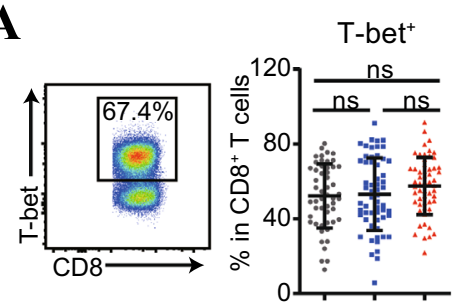

C
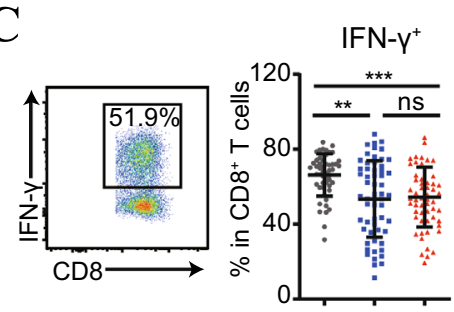

$\mathbf{E}$
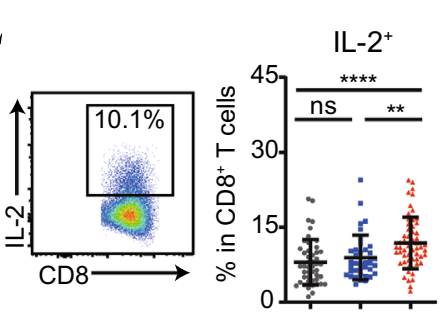

G
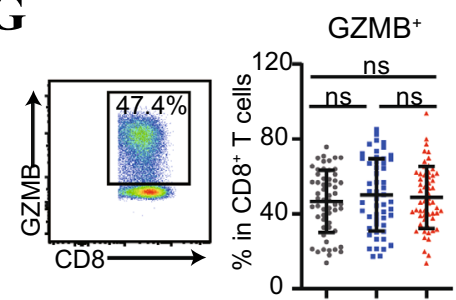

I
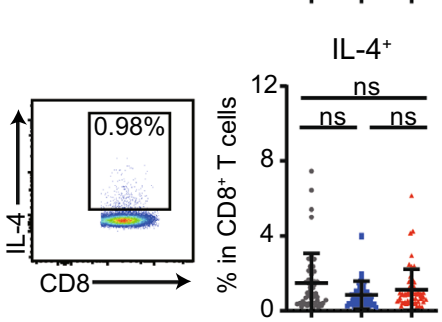

K

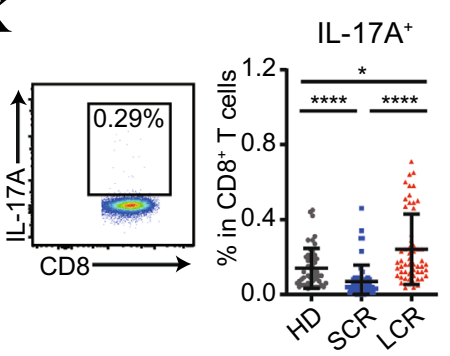

B T-bet ${ }^{+}$
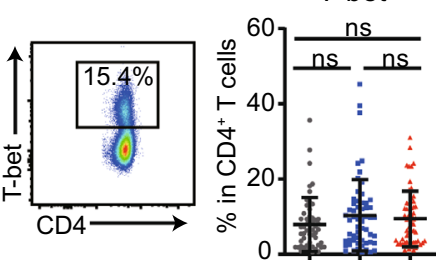

D
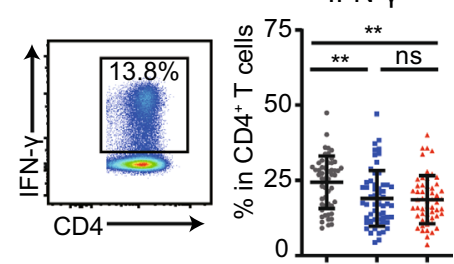

F
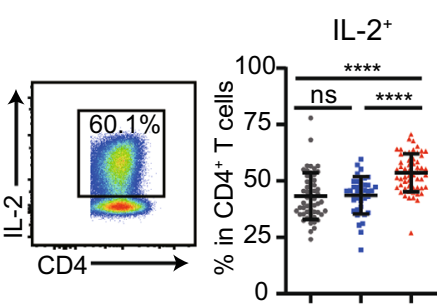

\section{$\mathbf{H}$}
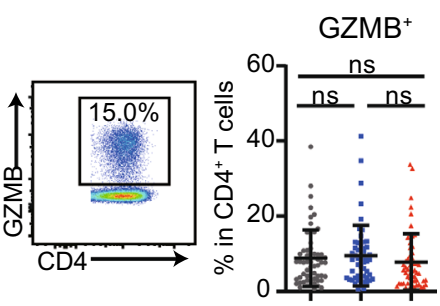

J

$\mathrm{IL}-4^{+}$
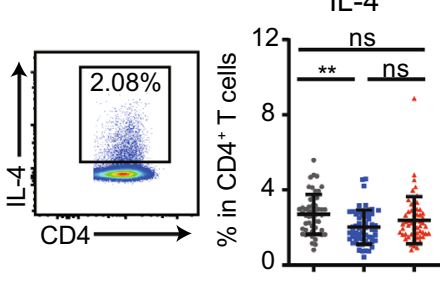

$\mathbf{L}$

IL-17A ${ }^{+}$
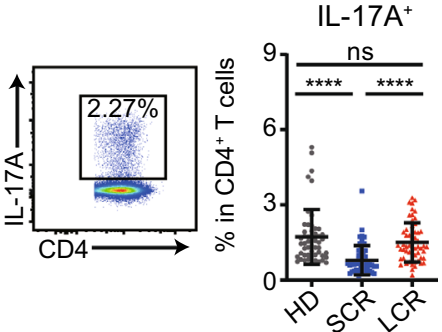

were much higher than that of the SCR cohort, but were still slightly lower than that of the HD cohort (Fig. 4A). The cTfh cells could be further organized into three subsets with different capabilities: cTfh 1 (CCR6 $\left.{ }^{-} \mathrm{CXCR} 3^{+}\right)$, cTfh2 (CCR6 ${ }^{-} \mathrm{CXCR}^{-}{ }^{-}$), and cTfh17 $\left(\mathrm{CCR}^{+}{ }^{+} \mathrm{CXCR}^{-}{ }^{-}\right)$ (Morita et al. 2011). Different from the SCR cohort, all three of the cTfh subsets in LCR were almost comparable with the HD cohort (Fig. 4B), from the perspective of the composition of cTfh. The frequency of the three cTfh subsets in $\mathrm{CD}^{+} \mathrm{T}$ cells of LCR were also recovered, nearly the same as that of HD (Supplementary Fig. S4). Additionally, the expression level of activation marker 
A

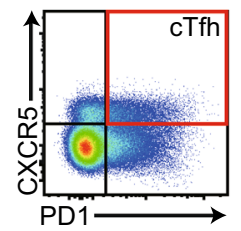

B

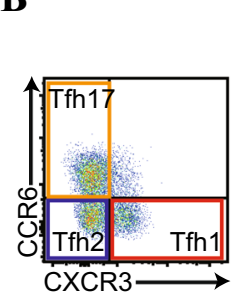

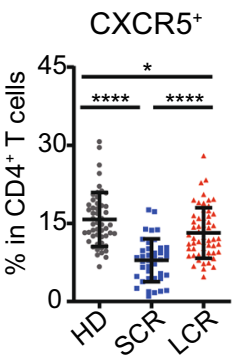

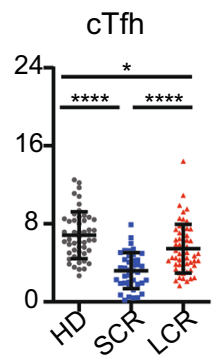

C

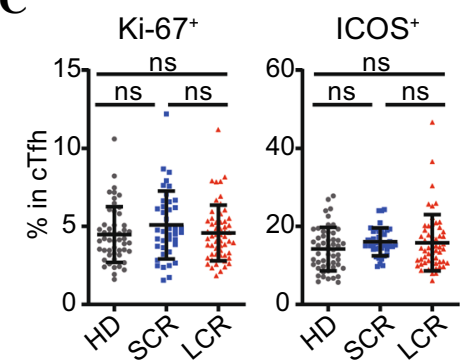

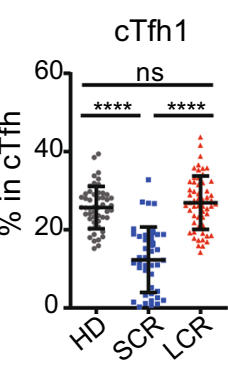

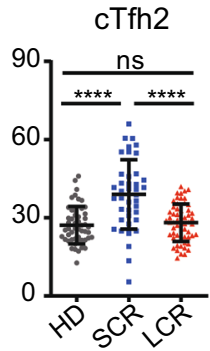

cTfh17

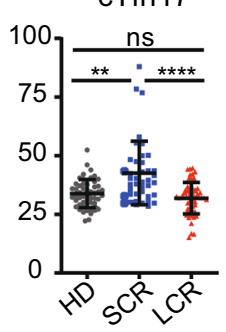

Fig. 4 Categorical subsets, proliferation and activation of circulating Tfh (cTfh) cells in PBMCs of HD, SCR and LCR cohorts. A-C PBMCs were co-stained with phenotypic markers and proliferation marker Ki-67 and were analyzed by flow cytometry. A Gating strategy of circulating Tfh cells (cTfh), and frequencies of CXCR5 ${ }^{+}$ $\mathrm{CD} 4^{+} \mathrm{T}$ cells, $\mathrm{CXCR} 5^{+} \mathrm{PD}-1^{+} \mathrm{CD} 4^{+}$circulating $\mathrm{Tfh}$ (cTfh) cells. B Gating strategies of cTfh subsets, and frequencies of $\mathrm{CXCR}^{+}$

ICOS and proliferation marker Ki-67 in cTfh cells of LCR were not different from that of HD (Fig. 4C). All data indicated the frequency and status of cTfh in LCR eventually returned to nearly the same as that in HD.

\section{Sustained SARS-CoV-2 Specific IFN- $\gamma^{+}$T Cell Responses}

Although the general immunological status of $\mathrm{T}$ cells in the LCR cohort had recovered toward base line, the IFN- $\gamma$ secreting potential was still remarkably reduced. We thus wondered whether the SARS-CoV-2 specific $\mathrm{T}$ cell responses declined after a long period of recovery. Therefore, ELISpot assay was performed under the stimulation of SARS-CoV-2 protein S1, S2, $\mathrm{N}$ or a negative control protein HIV-1 p24. We found that similar to the SCR cohort, SARS-CoV-2 specific IFN- $\gamma^{+} \mathrm{T}$ cell responses could also be detected in the LCR cohort. In terms of antigen specificity, significantly higher levels of S2 and $\mathrm{N}$ specific IFN- $\gamma^{+}$T cell responses could be observed in the SCR and LCR cohorts (Fig. 5). In contrast, level of S1 specific IFN- $\gamma^{+} \mathrm{T}$ cell response was much lower than that of $\mathrm{S} 2$ and $\mathrm{N}$ specific T cell responses in the SCR and LCR cohorts. More importantly, the S1, S2, and N specific IFN$\gamma^{+} \mathrm{T}$ cell responses in LCR were all comparable to that of SCR. This suggested that, in the LCR cohort, SARS-CoV-2 specific IFN- $\gamma^{+} \mathrm{T}$ cell responses were sustained.
CCR6 $^{-}$cells (cTfh1), $\mathrm{CXCR}^{-} \mathrm{CCR}^{-}$cells (cTfh2) and CXCR3 ${ }^{-}$ $\mathrm{CCR6}^{+}$(cTfh17) in cTfh cells. C Frequencies of proliferated Ki-67 cTfh cells and activated $\mathrm{ICOS}^{+}$cTfh cells. Results are shown as mean \pm S.D. One-way ANOVA was used to analyze the statistical difference between the three cohorts. ns, non-significant; $* P<0.05$; $* * P<0.01 ; * * * * P<0.0001$.

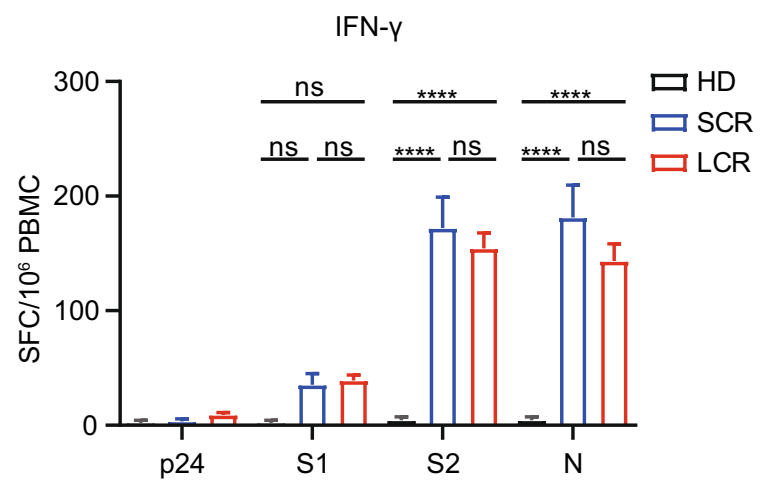

Fig. 5 SARS-CoV-2 specific T cell responses in PBMCs of HD, SCR and LCR cohorts. IFN- $\gamma$ producing $\mathrm{T}$ cells were measured by ELISpot under the stimulation of the SARS-CoV-2 N protein, S1 protein, S2 protein or irrelevant HIV-1 p24 protein. Data were obtained from 18 subjects in the HD cohort, 27 subjects in the SCR cohort and 57 subjects in the LCR cohort. Results are expressed as mean \pm S.E.M. Statistical difference was calculated with two-way ANOVA. ns, nonsignificant; $* * * * P<0.0001$.

\section{Discussion}

How long the $\mathrm{T}$ cell respond in convalescent COVID-19 patients against re-infection is still a big question. The protection time might greatly affect the prevalence of the pandemic (Kissler et al. 2020). Besides antibody response, $\mathrm{T}$ cell responses also play key roles in viral control. However, it is still unknown, after a long period of 
recovery, whether the altered non-specific $\mathrm{T}$ cell responses would resume, and whether the SARS-CoV-2 specific T cell responses would be sustained. Hence, in the present study, we established a COVID-19 long-time clinically recovered (20-26 weeks) cohort (LCR), an age and sex matched short-time clinically recovered (4-9 weeks) cohort (SCR) and an uninfected healthy donor cohort (HD) (Fig. 1). We then analyzed the non-specific and SARS$\mathrm{CoV}$-2-specific $\mathrm{T}$ cell responses in PBMCs of those three cohorts.

Phenotypic analysis showed that the differentiation of $\mathrm{CD}^{+} \mathrm{T}$ or $\mathrm{CD} 4^{+} \mathrm{T}$ cells in $\mathrm{LCR}$ was comparable to $\mathrm{HD}$, although the repression on activation marker PD-1 in $\mathrm{CD} 4^{+} \mathrm{T}$ cells, and the elevation of proliferation marker Ki67 in $\mathrm{CD}^{+} \mathrm{T}$ cells still exist (Figs. 2, 6). Functional potential analysis under non-specific stimulation indicated that different from IL-4 and IL-17, repression on IFN- $\gamma$ secretion by $\mathrm{CD} 8^{+} \mathrm{T}$ and $\mathrm{CD} 4^{+} \mathrm{T}$ cells were still prominent in LCR (Figs. 3, 6). Moreover, increase of IL-2 production became prominent. For $\mathrm{CD} 4^{+} \mathrm{T}$ cells, although the frequency of cTfh was not completely recovered, the composition, activation and proliferation levels of cTfh became similar to that of HD (Figs. 4, 6). In conclusion, our study showed that some non-specific $\mathrm{T}$ cell responses have recovered after 20-26 weeks of discharge.

In the process of our cohort establishment, potentially influential factors such as sex, age, and the presence of severe illness were all tracked as strictly as possible. Hence, we could still find the long-term alteration induced by COVID- 19 by comparing the HD, SCR and LCR cohorts, although with the caveat that the individuals recruited for the SCR cohort were not the same people recruited for the LCR cohort, and the SARS-CoV-2 specific T cell response in HD and SCR were only tested in sub-cohorts. Another limitation is that all analyses have been performed on PBMCs. In SCR, the individuals were clinically recovered from COVID-19 for 4-9 weeks. At this time point, the changes in PBMCs may not necessarily reflect changes in the frequency at the actual site of action (the lung) or secondary lymphoid compartments. But in LCR, the individuals were clinically recovered from COVID-19 for 20-26 weeks, and so the immune systems became quiescent, leading to the realization that the differences in PBMCs between LCR and HD could actually reflect the long-term effects of COVID-19.

The loss of Bcl-6-expressing Tfh cells and germinal centers in COVID-19 patients suggest an underlying basis for the lower quality and lack of durability of humoral immune responses observed during natural infection with SARS-CoV-2 (Kaneko et al. 2020). Consistent with this observation, we found profoundly reduced cTfh in PBMCs, even in those individuals clinically recovered after 4 to 9 weeks. But in the LCR cohort, the reduced cTfh could be eventually recovered, though still at lower rates than that of HD.

A recent study of COVID-19 convalescent individuals highlighted that SARS-CoV-2 specific $\mathrm{T}$ cells sharply declined within one month of clinical recovery ( $\mathrm{Ni}$ et al. 2020). Fortunately, compared with 4-9 weeks post clinical recovery, the SARS-CoV-2 specific T cell responses didn't decline after 20-26 weeks. We also found that SARSCoV-2 N, S2 and S1 specific IFN- $\gamma^{+} \mathrm{T}$ cell responses in LCR were comparable to those in SCR (Figs. 5, 6). The SARS-CoV-2 specific $\mathrm{T}$ cell responses were supposed to be negatively related with degrees of disease severity (Canete and Vinuesa 2020; Rydyznski Moderbacher et al. 2020). It
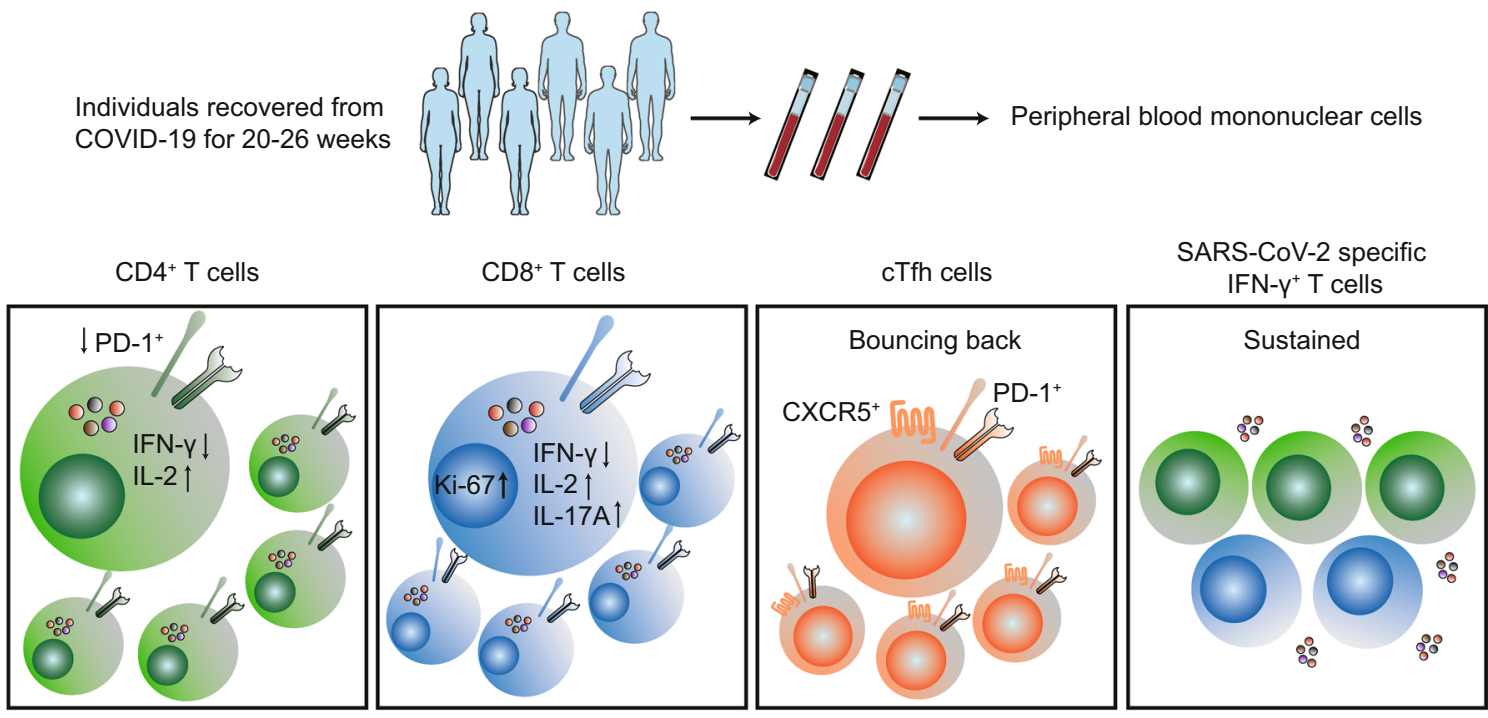

Fig. 6 Overview of alterations in peripheral T lymphocytes in individuals clinically recovered from COVID-19 for 20-26 weeks compared with healthy donors. $\uparrow$, increased frequency; $\downarrow$, decreased frequency. 
is important to consider that $\mathrm{T}$ cell responses against $\mathrm{N}$ and $\mathrm{S}$ proteins of SARS-CoV can still be detected in PBMCs of recovered patients for years (Liu et al. 2017). We could speculate that the SARS-CoV-2 specific T cell responses in COVID-19 convalescent individuals might remain for a relatively long time, which may help to resist SARS-CoV-2 re-infection.

In another sense, $\mathrm{CD}^{+} \mathrm{T}$ cells and $\mathrm{CD}^{+} \mathrm{T}$ cells are both critical for the control of intracellular pathogen infections and tumors (Douek et al. 2002; Yang et al. 2016). Hence, attention should be paid to the fact that the long-term dysfunction of $\mathrm{T}$ cells might impair the immune surveillance and protection in COVID-19 clinically recovered individuals. The long-lasting dysfunction of lymphocytes is common in patients infected by viruses which could induce chronic infection such as HIV and HCV (Douek et al. 2002; Ahmed et al. 2019), but is rarely reported in patients infected by viruses which only induce acute infection. Moreover, it is surprising that, while the IFN- $\gamma$-producing potential was remarkably repressed, the expression of the IFN- $\gamma$ upstream transcription factor T-bet in $\mathrm{T}$ cells did not change. In addition, there were no significant differences in the frequencies of Teff, Tem, Tcm and Tna in both $\mathrm{CD}^{+} \mathrm{T}$ and $\mathrm{CD}^{+}{ }^{+} \mathrm{T}$ cells. Hence, we can infer that COVID-19 might leave imprints on transcription, translation or stability of IFN- $\gamma$ mRNA or protein. The "imprint" on the functional potential of $\mathrm{T}$ cells requires further study in the future.

Acknowledgements We would like to thank the COVID-19 recovered individuals and healthy donors involved in this study, and the medical staff at Wuhan Jinyintan Hospital. We also thank Professor Ningshao $\mathrm{Xia}$ for generously providing the recombinant SARS-CoV-2 specific $\mathrm{N}$ protein. This work was supported by National Natural Science Foundation of China (31970881).

Author contributions BZ, JY and MZ contributed to the conception, design, data acquisition, analysis, interpretation and drafted and revised the manuscript. QY, KH, JX, XL and YL contributed to the sample collection and acquisition of data. YC, JY, CH and $\mathrm{HY}$ contributed to the study concept and design, data analysis, interpretation and revised the manuscript. All authors gave final approval and agreed to be accountable for all aspects of the work.

\section{Compliance with Ethical Standards}

Conflict of interest The authors declare no conflict of interest.

Animal and Human Rights Statement This study was approved by the Medical Ethical Committee of Wuhan Jinyintan hospital (Number KY-2020-47.01). All COVID-19 recovered patients and healthy donors signed a written informed consent to use their biological samples and clinical data for research purposes.

\section{References}

Ahmed F, Ibrahim A, Cooper CL, Kumar A, Crawley AM (2019) Chronic hepatitis $\mathrm{C}$ virus infection impairs M1 macrophage differentiation and contributes to $\mathrm{CD} 8(+)$ T-cell dysfunction. Cells 8:374

Callaway E (2020) Coronavirus vaccines: five key questions as trials begin. Nature 579:481

Canete PF, Vinuesa CG (2020) COVID-19 makes B cells forget, but $\mathrm{T}$ cells remember. Cell 183:13-15

Cao B, Wang Y, Wen D, Liu W, Wang J, Fan G, Ruan L, Song B, Cai Y, Wei M, Li X, Xia J, Chen N, Xiang J, Yu T, Bai T, Xie X, Zhang L, Li C, Yuan Y, Chen H, Li H, Huang H, Tu S, Gong F, Liu Y, Wei Y, Dong C, Zhou F, Gu X, Xu J, Liu Z, Zhang Y, Shang L, Wang K, Li K, Zhou X, Dong X, Qu Z, Lu S, Hu X, Ruan S, Luo S, Wu J, Peng L, Cheng F, Pan L, Zou J, Jia C, Liu X, Wang S, Wu X, Ge Q, He J, Zhan H, Qiu F, Guo L, Huang C, Jaki T, Hayden FG, Horby PW, Zhang D, Wang C (2020) A trial of Lopinavir-Ritonavir in adults hospitalized with severe covid19. N Engl J Med. https://doi.org/10.1056/NEJMoa2001282

Corey L, Mascola JR, Fauci AS, Collins FS (2020) A strategic approach to COVID-19 vaccine R\&D. Science 368:948-950

Cox RJ, Brokstad KA (2020) Not just antibodies: B cells and T cells mediate immunity to COVID-19. Nat Rev Immunol. https://doi. org/10.1038/s41577-020-00436-4

Crotty S (2019) T follicular helper cell biology: a decade of discovery and diseases. Immunity 50:1132-1148

Douek DC, Brenchley JM, Betts MR, Ambrozak DR, Hill BJ, Okamoto Y, Casazza JP, Kuruppu J, Kunstman K, Wolinsky S, Grossman Z, Dybul M, Oxenius A, Price DA, Connors M, Koup RA (2002) HIV preferentially infects HIV-specific CD4+ T cells. Nature 417:95-98

Grifoni A, Weiskopf D, Ramirez SI, Mateus J, Dan JM, Moderbacher CR, Rawlings SA, Sutherland A, Premkumar L, Jadi RS, Marrama D, de Silva AM, Frazier A, Carlin AF, Greenbaum JA, Peters B, Krammer F, Smith DM, Crotty S, Sette A (2020) Targets of $\mathrm{T}$ cell responses to SARS-CoV-2 coronavirus in humans with COVID-19 disease and unexposed individuals. Cell 181:1489-1501.e1415

Kaneko N, Kuo HH, Boucau J, Farmer JR, Allard-Chamard H, Mahajan VS, Piechocka-Trocha A, Lefteri K, Osborn M, Bals J, Bartsch YC, Bonheur N, Caradonna TM, Chevalier J, Chowdhury F, Diefenbach TJ, Einkauf K, Fallon J, Feldman J, Finn KK, Garcia-Broncano P, Hartana CA, Hauser BM, Jiang C, Kaplonek P, Karpell M, Koscher EC, Lian X, Liu H, Liu J, Ly NL, Michell AR, Rassadkina Y, Seiger K, Sessa L, Shin S, Singh N, Sun W, Sun X, Ticheli HJ, Waring MT, Zhu AL, Alter G, Li JZ, Lingwood D, Schmidt AG, Lichterfeld M, Walker BD, Yu XG, Padera RF Jr, Pillai S, Massachusetts Consortium on Pathogen Readiness Specimen Working G (2020) Loss of Bcl-6-expressing $\mathrm{T}$ follicular helper cells and germinal centers in COVID-19. Cell 183:143-157.e113

Kissler SM, Tedijanto C, Goldstein E, Grad YH, Lipsitch M (2020) Projecting the transmission dynamics of SARS-CoV-2 through the postpandemic period. Science 368:860-868

Leslie M (2020) T cells found in coronavirus patients "bode well" for long-term immunity. Science 368:809-810

Liu WJ, Zhao M, Liu K, Xu K, Wong G, Tan W, Gao GF (2017) T-cell immunity of SARS-CoV: implications for vaccine development against MERS-CoV. Antiviral Res 137:82-92

Long D, Chen Y, Wu H, Zhao M, Lu Q (2019) Clinical significance and immunobiology of IL-21 in autoimmunity. J Autoimmun 99:1-14

Long QX, Tang XJ, Shi QL, Li Q, Deng HJ, Yuan J, Hu JL, Xu W, Zhang Y, Lv FJ, Su K, Zhang F, Gong J, Wu B, Liu XM, Li JJ, 
Qiu JF, Chen J, Huang AL (2020) Clinical and immunological assessment of asymptomatic SARS-CoV-2 infections. Nat Med 26:1200-1204

Lucas C, Wong P, Klein J, Castro TBR, Silva J, Sundaram M, Ellingson MK, Mao $\mathrm{T}$, Oh JE, Israelow $\mathrm{B}$, Takahashi $\mathrm{T}$, Tokuyama M, Lu P, Venkataraman A, Park A, Mohanty S, Wang H, Wyllie AL, Vogels CBF, Earnest R, Lapidus S, Ott IM, Moore AJ, Muenker MC, Fournier JB, Campbell M, Odio CD, Casanovas-Massana A, Yale IT, Herbst R, Shaw AC, Medzhitov R, Schulz WL, Grubaugh ND, Dela Cruz C, Farhadian S, Ko AI, Omer SB, Iwasaki A (2020) Longitudinal analyses reveal immunological misfiring in severe COVID-19. Nature 584:463-469

Mathew D, Giles JR, Baxter AE, Oldridge DA, Greenplate AR, Wu JE, Alanio C, Kuri-Cervantes L, Pampena MB, D'Andrea K, Manne S, Chen Z, Huang YJ, Reilly JP, Weisman AR, Ittner CAG, Kuthuru O, Dougherty J, Nzingha K, Han N, Kim J, Pattekar A, Goodwin EC, Anderson EM, Weirick ME, Gouma S, Arevalo CP, Bolton MJ, Chen F, Lacey SF, Ramage H, Cherry S, Hensley SE, Apostolidis SA, Huang AC, Vella LA, Unit UPCP, Betts MR, Meyer NJ, Wherry EJ (2020) Deep immune profiling of COVID-19 patients reveals distinct immunotypes with therapeutic implications. Science 369:15

Morita R, Schmitt N, Bentebibel SE, Ranganathan R, Bourdery L, Zurawski G, Foucat E, Dullaers M, Oh S, Sabzghabaei N, Lavecchio EM, Punaro M, Pascual V, Banchereau J, Ueno H (2011) Human blood CXCR5(+)CD4(+) T cells are counterparts of $\mathrm{T}$ follicular cells and contain specific subsets that differentially support antibody secretion. Immunity 34:108-121

Ni L, Ye F, Cheng ML, Feng Y, Deng YQ, Zhao H, Wei P, Ge J, Gou M, Li X, Sun L, Cao T, Wang P, Zhou C, Zhang R, Liang P, Guo H, Wang X, Qin CF, Chen F, Dong C (2020) Detection of SARS-CoV-2-specific humoral and cellular immunity in COVID-19 convalescent individuals. Immunity 52:971-977.e973

Peng Y, Mentzer AJ, Liu G, Yao X, Yin Z, Dong D, Dejnirattisai W, Rostron T, Supasa P, Liu C, Lopez-Camacho C, Slon-Campos J, Zhao Y, Stuart DI, Paesen GC, Grimes JM, Antson AA, Bayfield OW, Hawkins D, Ker DS, Wang B, Turtle L, Subramaniam K, Thomson P, Zhang P, Dold C, Ratcliff J, Simmonds P, de Silva T, Sopp P, Wellington D, Rajapaksa U, Chen YL, Salio M, Napolitani G, Paes W, Borrow P, Kessler BM, Fry JW, Schwabe NF, Semple MG, Baillie JK, Moore SC, Openshaw PJM, Ansari MA, Dunachie S, Barnes E, Frater J, Kerr G, Goulder P, Lockett $\mathrm{T}$, Levin R, Zhang Y, Jing R, Ho LP, Oxford Immunology Network Covid-19 Response TcC, Investigators IC, Cornall RJ, Conlon CP, Klenerman P, Screaton GR, Mongkolsapaya J, McMichael A, Knight JC, Ogg G, Dong T (2020) Broad and strong memory CD4(+) and CD8(+) T cells induced by SARSCoV-2 in UK convalescent individuals following COVID-19. Nat Immunol. https://doi.org/10.1038/s41590-020-0782-6

Qin C, Zhou L, Hu Z, Zhang S, Yang S, Tao Y, Xie C, Ma K, Shang K, Wang W, Tian DS (2020) Dysregulation of Immune Response in Patients With Coronavirus 2019 (COVID-19) in Wuhan, China. Clin Infect Dis 71:762-768
Rydyznski Moderbacher C, Ramirez SI, Dan JM, Grifoni A, Hastie KM, Weiskopf D, Belanger S, Abbott RK, Kim C, Choi J, Kato Y, Crotty EG, Kim C, Rawlings SA, Mateus J, Tse LPV, Frazier A, Baric R, Peters B, Greenbaum J, Ollmann Saphire E, Smith DM, Sette A, Crotty S (2020) Antigen-specific adaptive immunity to SARS-CoV-2 in acute COVID-19 s. Cell. https:// doi.org/10.1016/j.cell.2020.09.038

Sekine T, Perez-Potti A, Rivera-Ballesteros O, Stralin K, Gorin JB, Olsson A, Llewellyn-Lacey S, Kamal H, Bogdanovic G, Muschiol S, Wullimann DJ, Kammann T, Emgard J, Parrot T, Folkesson E, Karolinska C-SG, Rooyackers O, Eriksson LI, Henter JI, Sonnerborg A, Allander T, Albert J, Nielsen M, Klingstrom J, Gredmark-Russ S, Bjorkstrom NK, Sandberg JK, Price DA, Ljunggren HG, Aleman S, Buggert M (2020) Robust $\mathrm{T}$ cell immunity in convalescent individuals with asymptomatic or mild COVID-19. Cell 183:158-168.e114

Thevarajan I, Nguyen THO, Koutsakos M, Druce J, Caly L, van de Sandt CE, Jia X, Nicholson S, Catton M, Cowie B, Tong SYC, Lewin SR, Kedzierska K (2020) Breadth of concomitant immune responses prior to patient recovery: a case report of non-severe COVID-19. Nat Med 26:453-455

Yang W, Bai Y, Xiong Y, Zhang J, Chen S, Zheng X, Meng X, Li L, Wang J, Xu C, Yan C, Wang L, Chang CC, Chang TY, Zhang T, Zhou P, Song BL, Liu W, Sun SC, Liu X, Li BL, Xu C (2016) Potentiating the antitumour response of $\mathrm{CD} 8(+) \mathrm{T}$ cells by modulating cholesterol metabolism. Nature 531:651-655

Yang J, Zhang E, Zhong M, Yang Q, Hong K, Shu T, Zhou D, Xiang J, Xia J, Zhou X, Zhang D, Huang C, Shang Y, Yan H (2020a) Longitudinal characteristics of $\mathrm{T}$ cell responses in asymptomatic SARS-CoV-2 infection. Virol Sin. https://doi.org/10.1007/ s12250-020-00277-4

Yang J, Zhong M, Zhang E, Hong K, Yang Q, Zhou D, Xia J, Chen Y, Sun M, Zhao B, Xiang J, Liu Y, Han Y, Zhou X, Huang C, Y. S, Yan H (2020b) Broad phenotypic alterations and potential dysfunctions of lymphocytes in COVID-19 recovered individuals. Preprint at medRxiv

Zhang X, Tan Y, Ling Y, Lu G, Liu F, Yi Z, Jia X, Wu M, Shi B, Xu S, Chen J, Wang W, Chen B, Jiang L, Yu S, Lu J, Wang J, Xu M, Yuan Z, Zhang Q, Zhang X, Zhao G, Wang S, Chen S, Lu H (2020) Viral and host factors related to the clinical outcome of COVID-19. Nature 583:437-440

Zhou T, Su TT, Mudianto T, Wang J (2020) Immune asynchrony in COVID-19 pathogenesis and potential immunotherapies. J Exp Med 217:e20200674

Zhu L, Yang P, Zhao Y, Zhuang Z, Wang Z, Song R, Zhang J, Liu C, Gao Q, Xu Q, Wei X, Sun HX, Ye B, Wu Y, Zhang N, Lei G, Yu L, Yan J, Diao G, Meng F, Bai C, Mao P, Yu Y, Wang M, Yuan Y, Deng Q, Li Z, Huang Y, Hu G, Liu Y, Wang X, Xu Z, Liu P, Bi Y, Shi Y, Zhang S, Chen Z, Wang J, Xu X, Wu G, Wang FS, Gao GF, Liu L, Liu WJ (2020) Single-cell sequencing of peripheral mononuclear cells reveals distinct immune response landscapes of COVID-19 and influenza patients. Immunity 53:685-696.e683 